\title{
PENAMBAHAN MINYAK MENTAH DENGAN KONSENTRASI BERBEDA TERHADAP FISIOLOGI IKAN CLOWNFISH (Amphiprion percula)
}

The addition of crude oil with different concentration to fisiologi of Clownfish (Amphiprion percula)

\author{
Kade Devilarashati ${ }^{1}$, Rangga Bayu Kusuma Haris ${ }^{2}$, Syaeful Anwar ${ }^{2}$, Tyas Dita \\ Pramesthy $^{3}$, Yuli Yulianti ${ }^{4}$, dan Arumwati $^{5}$ \\ 1) Fakultas Perikanan Universitas PGRI Palembang \\ 2) Staf Pengajar Fakultas Perikanan Universitas PGRI Palembang \\ 3) Staf Pengajar Politeknik Kelautan dan Perikanan Dumai \\ 4) Staf Pegawai Balai Besar Perikanan Budidaya Laut Lampung \\ 5) Satuan Pengawas Sumber Daya Kelautan dan Perikanan Palembang \\ Email : ranggabkh@gmail.com
}

\begin{abstract}
Abstrak
Penelitian ini bertujuan untuk Untuk menganalisis penambahan minyak mentah dengan konsentrasi yang berbeda terhadap fisiologi meliputi tingkah laku, bentuk badan, kulit dan insang pada ikan Clownfish (Amphiprion percula). Kegiatan penelitian dilaksanakan bulan Desember 2017 - Januari 2018 di Laboratorium Basah Balai Besar Perikanan Budidaya Laut Lampung. Metode yang digunakan adalah eksperimental dengan Rancangan Acak Lengkap (RAL) 4 taraf perlakuan dan 3 taraf ulangan.Perlakuan penambahan minyak mentah adalah sebagai berikut, P0 (tanpa penambahan), P1 (konsentrasi 0,013 mg/l), P2 (konsentrasi 0,130 mg/l) dan P3 (konsentrasi 1,295 mg/l). Hasil penelitian diperoleh meliputi tingkah laku, bentuk badan, kulit dan insang pada ikan Clownfish (Amphiprion percula) menunjukan bahwa ikan Clownfish (Amphiprion percula) masing-masing perlakuan mengalami stress karena adanya kandungan senyawa hidrokarbon mengakibatkan tingkah laku ikan tidak menentu. Selain itu hal ini juga berpengaruh pada senyawa kimia pada minyak mentah dapat merusak bentuk badan dan insang karena adanya tumpuk minyak mentah pada lampiran filament yang menghalangi proses respirasi, pada kulit dalam penelitian ini dalam kondisi normal tidak ada luka.
\end{abstract}

Kata Kunci : Minyak Mentah, Ikan Clownfish (Amphiprion percula), fisiologi 


\section{PENDahuluan}

Pencemaran laut sendiri dalam Peraturan Pemerintah Republik Indonesia Nomor 24 Tahun 1991 tentang pengendalian pencemaran dan atau perusakan laut, didefinisikan sebagai masuknya atau dimasukkannya makhluk hidup, zat, energi, danatau komponen lain ke dalam lingkungan laut oleh kegiatan manusia sehingga kualitasnya turun sampai tingkat tertentu yang menyebabkan lingkungan laut tidak sesuai lagi dengan baku mutu danatau fungsinya. Dampak negatifnya sendiri diantaranya,penangkapan ikan yang tidak dimbangi oleh hasil budidaya, sehingga terjadinya eksploitasi yang tidak terkendali (Over Fishing) dan juga pencemaran minyak ke lingkungan perairan dan laut (Setiawan dkk, 2014).

Pencemaran minyak ini dapat menimbulkan polusi terhadap perairan dan laut yang berdampak pada turunnya daya dukung lingkungan yang berdampak pada terganggunya kehidupan organisme dalam perairan tersebut.Sebab itu, setiap awak kapal wajib melakukan pencegahan dan menanggulangi pencemaran yang bersumber dari kapalnya (Setiawan dkk, 2014).Menurut Nuryanti and Edi (2010), pencemaran minyak di dalam air dapat terjadi karena adanya kegiatan eksploitasi minyak bumi, pengilangan minyak, kecelakaan trasportasi atau kebocoran pipa. Ikan Clownfish (Amphiprion percula) merupakan ikan hias laut yang terdapat diperairan dangkal dengan ke dalaman 2 meter selain itu ikan Clownfish (Amphiprion percula) termasuk ikan perenang yang lambat sehingga memanfaatkan keberadaan anemon sebagai tempat persembunyian dari ikan - ikan pemangsa (predator). Penelitian ini bertujuan : Untuk menganalisis penambahan minyak mentah dengan konsentrasi yang berbeda terhadap fisiologi meliputi tingkah laku, bentuk badan, kulit dan insang pada ikan Clownfish (Amphiprion percula)?

\section{METODE PENELITIAN}

Penelitian telah dilakukan pada bulan 26 Desember 2017 - 22 Januari 2018 bertempat di Laboratorium Clownfish Balai Besar Perikanan Budidaya Laut Lampung, Jalan Yos Sudarso, Desa Hanura, Kecamatan Padang Cermin, Kabupaten Pasewaran 35454, Provinsi Lampung Tlp (0721) 400139/4001380 Faxsimile (0721) 4001110. Penelitian ini menggunakan metode Rancangan Acak Lengkap (RAL) dengan 4 (empat) perlakuan dan diulang sebanyak 3 (tiga kali). Penambahan minyak dalam penelitian ini berdasarkan penelitian terdahulu yang dilakukan oleh Syafriadiman dkk, (2009) pada benih Kerapu Bebek (Cromileptis altivelis). Konsentrasi yang digunakan dalam penelitian ini adalah hasil dari penelitian pendahuluan yang dilakukan oleh Syafriadiman dkk, (2009) dengan konsentrasi terrendah $0,685 \mathrm{mg} / \mathrm{l}$ dan konsentrasi tertinggi $2,452 \mathrm{mg} / \mathrm{l}$ dari hasil penelitian pendahuluan tersebut diperoleh konsentrasi seperti di bawah ini, yang di gunakan dalam penelitian ini.

P0 : Perlakuan tanpa penambahan minyak mentah terhadap biota uji (sebagai terkontrol).

P1 : Perlakuan penambahan minyak mentah sebanyak 0,013 mg/l dalam wadah yang berisi biota uji setiap hari sampai mortalitas.

P2 : Perlakuan penambahan minyak mentah sebanyak $0,130 \mathrm{mg} / \mathrm{l}$ dalam wadah yang berisi biota uji setiap hari sampai mortalitas.

P3 : Perlakuan penambahan minyak mentah sebanyak 1,295 mg/l dalam wadah yang berisi biota uji setiap hari sampai mortalitas.

Biota uji yang digunakan adalah ikan clownfish (Amphiprion percula) dengan ukuran $3 \mathrm{~cm}$, berumur 3 bulan. Benih ikan Clownfish ini berasal dari hasil pembenihan yang dilakukan di Laboratorium Clownfish di Balai Besar Perikanan Budidaya Laut Lampung dengan jumlah ikan yang digunakan sebanyak 120 ekor dan masing-masing akuarium diisi dengan ikan sebanyak 10 ekor/akuarium. Bahan uji yang digunakan adalah minyak mentah yang didapat dari galian sumur minyak oleh warga di Desa Keluang Kabupaten Musi Banyuasin.

Media yang digunakan dalam penelitian ini adalah akuarium dengan ukuran $40 \mathrm{~cm}$ x 40 $\mathrm{cm}$ x $40 \mathrm{~cm}$ dengan volume air 65 liter air, air yang digunakan adalah air laut yang diambil dari laut, sebelum air laut digunakan dilakukan proses penyaringan sehingga air yang digunakan adalah air yang sudah sesuai dengan kebutuhan hidup Ikan Clownfish (Amphiprion percula.). Penelitian ini dilakukan pengamatan terhadap kondisi morfologi dimana yang diamati meliputi, tingkah laku, bentuk badan (sirip dada, sirip perut, sirip punggung, sirip anus dan sirip anal) dan kualitas air yang terdiri dari DO, suhu, salinitas, $\mathrm{pH}$, amoniak dan nitrit. Data yang diperloleh meliputi tingkah laku, bentuk badan (sirip dada, sirip perut, sirip pungung, sirip anal dan sirip ekor), kulit dan insang diolah secara deskriptif. 


\section{HASIL DAN PEMBAHASAN}

\section{Fisiologi Ikan Clownfish (Amphiprion percula).}

Hasil pengamatan fisiologi ikan dari penelitian mengenai penambahan minyak mentah dengan konsentrasi yang berbeda terhadap ikan Clownfish (Amphiprion percula) yang dilaksanakan di Laboratorium Basah Devisi Pakan Alami, Rumput Laut dan Ikan Hias (PALIASRU) Balai Besar Perikanan Budidaya Laut Lampung (BBPBL) selama 7 hari dengan jumlah pengamatan 7 kali dengan rentang waktu yang berbeda ( 2 jam, 4 jam, 8 jam, 12 jam, 24 jam, 48 jam, dan 96 jam) dengan biota uji sebanyak 120 ekor yang terbagi dalam 12 wadah. Perubahan bentuk fisiologis keadaan benih ikan Clownfish (Amphiprion percula) dapat diketahui setelah diberikan perlakuan.Perubahan fisiologi dan morfologi pada ikan setelah diberikan perlakuan terbagi menjadi 3 diantaranya, terlihat agak sehat, bergerak lemah dan mati yang ditunjukan pada Tabel 1.

Tabel 1. Perubahan Kondisi Ikan Clownfish Secara Morfologis Pada Ikan Terkontrol, Agak Sehat, Lemah, Dan Ikan Mati Selama Uji Dilakukan.

\begin{tabular}{|c|c|c|c|c|c|}
\hline \multirow[t]{2}{*}{ No } & \multirow[t]{2}{*}{ Pengamatan } & \multirow{2}{*}{$\begin{array}{c}\text { Ikan } \\
\text { terkontr } \\
\text { ol }\end{array}$} & \multicolumn{3}{|c|}{ Kondisi Ikan dengan Perlakuan Minyak Mentah } \\
\hline & & & $\begin{array}{l}\text { Agak } \\
\text { sehat }\end{array}$ & $\begin{array}{l}\text { Bergerak } \\
\text { lemah }\end{array}$ & Mati \\
\hline 1. & $\begin{array}{l}\text { Tingkah Laku } \\
\text { Pergerakan Ikan }\end{array}$ & Normal & Lemah & Lemah & $\begin{array}{l}\text { Tidak bergerak dan } \\
\text { berada di dasar akuarium }\end{array}$ \\
\hline 2. & $\begin{array}{l}\text { Bentuk Badan } \\
\text { Sirip Dada } \\
\text { Sirip Perut } \\
\text { Sirip Punggung }\end{array}$ & $\begin{array}{l}\text { Normal } \\
\text { Normal } \\
\text { Normal }\end{array}$ & $\begin{array}{l}\text { Normal } \\
\text { Normal } \\
\text { Normal }\end{array}$ & $\begin{array}{l}\text { Normal } \\
\text { Normal } \\
\text { Normal }\end{array}$ & $\begin{array}{l}\text { Geripis } \\
\text { Rusak } \\
\text { Rusak }\end{array}$ \\
\hline $\begin{array}{l}4 . \\
5 .\end{array}$ & $\begin{array}{l}\text { Sirip anal } \\
\text { Sirip Ekor } \\
\text { Kulit } \\
\text { Ingsang }\end{array}$ & $\begin{array}{l}\text { Normal } \\
\text { Normal } \\
\text { Normal } \\
\text { Normal }\end{array}$ & $\begin{array}{l}\text { Normal } \\
\text { Geripis } \\
\text { Normal } \\
\text { Rusak }\end{array}$ & $\begin{array}{c}\text { Geripis } \\
\text { Geripis } \\
\text { Normal } \\
\text { Rusak, putih } \\
\text { dan puntung }\end{array}$ & $\begin{array}{l}\text { Puntung } \\
\text { Puntung } \\
\text { Normal } \\
\text { Rusak, } \\
\text { puntung. }\end{array}$ \\
\hline
\end{tabular}

(Sumber : Data Penelitian, 2018)

Berdasarkan pemberian perlakuan minyak mentah dengan konsentrasi berbeda yang dilakukan pada biota uji dari hasil pengamatan yang dilakukan secara deskriptif perubahan tingkah laku pada perlakuan P0 $(0,000 \mathrm{mg} / \mathrm{l})$ tanpa minyak mentah, perlakuan

Tabel 2. Pengamatan Tingkah laku, Bentuk Badan, Sirip dan Ingsang Ikan Clownfish (Amphiprion percula).

\begin{tabular}{ccl}
\hline Kondisi Ikan & \multicolumn{1}{c}{ Tingkahlaku benih ikan Clownfish (Amphiption percula) } \\
\hline P0 (0,00 mg/l) & $\checkmark$ & Gerakan aktif, responsif terhadap pakan dan responsif terhadap rangsangan dari \\
& & luar. \\
& $\checkmark$ Kondisi sirip baik ( tidak ada yang rusak atau robek ) \\
& $\checkmark$ Bukaan mulut dan operculum terlihat normal. \\
& $\checkmark$ Insang berwarna merah cerah. \\
\hline P1 (0.013 mg/l) & $\checkmark$ & Pergerakan ikan aktif, responsif terhadap pakan dan responsif terhadap \\
& $\checkmark$ rangsangan dari luar. \\
& $\checkmark$ Kondisi sirip tidak baik ( geripis dan robek) \\
& $\checkmark$ Bukaan mulut dan operculum terlihat normal \\
& $\checkmark$ Insang berwarna merah cerah. \\
\hline P2 (0,130 mg/l) & $\checkmark$ & Pergerakan ikan lemah, responsif terhadap pakan dan Responsif terhadap \\
& $\checkmark$ rangsangan dari luar kurang. \\
& $\checkmark$ Kondisi sirip yang tidak baik (geripis dan robek ) \\
& $\checkmark$ Bukaan mulut dan operculum terlihat tidak normal. \\
& $\checkmark$ Insang berwarna merah pucat \\
\hline
\end{tabular}

P1 $(0,013 \mathrm{mg} / \mathrm{l})$ minyak mentah konsentrasi rendah, perlakuan P2 $(0,130 \mathrm{mg} / \mathrm{l})$ minyak mentah konsentrasi sedang, dan perlakuan P3 $(1,295 \mathrm{mg} / \mathrm{l})$ minyak mentah konsentrasi agak tinggi dalam Tabel 2. 


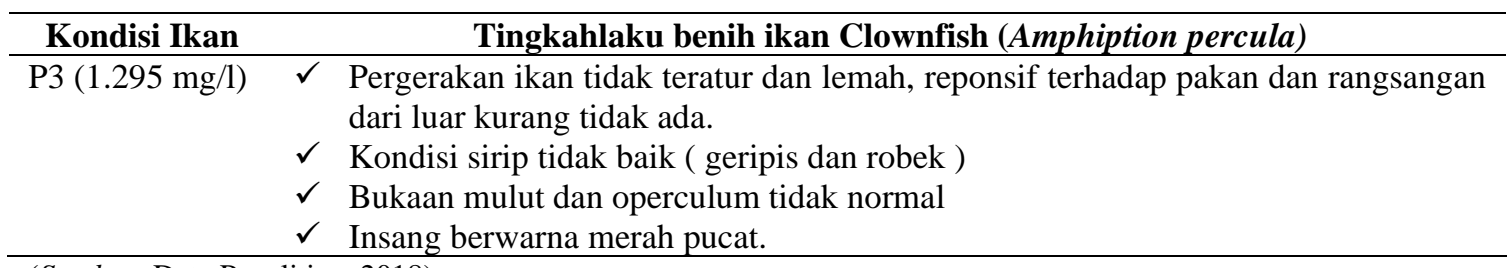

(Sumber :Data Penelitian, 2018)

Dari pengamatan Tabel 1 Dimana kondisi fisiologi dan morfologi ikan Clownfish (Amphiprion percula) selama uji dilakukan dimana pergerakan ikan yang berdasarkan pengamatan secara visual perubahan tingkah laku ikan mulai terjadi pada pengamatan ke 8 jam terlihat ketidak seimbangan ikan dalam berenang, pergerakan ikan cenderung berbentuk vertikal ke permukaan dan ikan akan berenang didasar yang pada akhirnya ikan tersebut mati. Kondisi bentuk badan (sirip dada, perut, pungung, anus dan anal) mengalami kerusakan pada pengamatan ke 8 jam yang dapat dilihat pada bagian lampiran untuk lebih jelas mengenai kerusakan pada bagian badan.

\section{a. Tingkah Laku.}

Dari Tabel 2 dimana tingkah laku ikan pada perlakuan terkontrol tidak mengalami perubahan pergerakan yang terlihat normal dimana ditandai dengan pergerakan renang secara horizontal serta aktif, lincah dan responsif terhadap pakan dan respon terhadap rangsangan dari luar baik. Pada perlakuan 0,013 $\mathrm{mg} / \mathrm{l}$ tingkah laku ikan terlihat mengalami perubahan dari pergerakan renang ikan yang terlihat sekali-kali berenang keatas dan kebawah.Responsif terhadap pakan yang diberikan serta masih ada respon terhadap rangsangan yang terjadi diluar.Pada perlakuan 0,130 $\mathrm{mg} / \mathrm{l}$ pergerakan ikan terlihat lemah, dimana renang ikan yang lebih banyak di dasar terkadang berenang keatas, pergerakan renang ikan terlihat vertikal.Secara responsif pakan yang berikan dan rangsangan dari luar yang kurang

.Pada kondisi perlakuan tertinggi 1,295 $\mathrm{mg} / \mathrm{l}$ tingkah laku biota uji terlihat dari pergerakan renang ikan yang tidak menentu, dimana ikan berenang vertikal ke atas dan kebawah, ikan lebih sering berada di bawah sekali-kali berusaha keatas menembus lapisan minyak pada permukaan air.Komponen hidrokabon yang bersifat racun berpengaruh pada reproduksi, perkembangan, pertumbuhan, dan perilaku biota laut, terutama plankton, bahkan dapat mematikan ikan, dengan sendirinya dapat menurunkan produksi ikan.

\section{b. Bentuk badan}

Bentuk badan yang diamati meliputi kondisi sirip dada, sirip perut, sirip pungung, sirip anal, dan sirip ekor untuk hasil dari pengamatan pada Tabel $\mathbf{1}$ dideskriptifkan berikut ini.

1) Sirip Dada

Kondisi sirip dada pada perlakuan terkontrol normal, tidak ada tanda sirip rusak atau puntung.Pada perlakuan terkontrol keadaan sirip dada terlihat normal.Pada konsentrasi 0,013 mg/l kondisi sirip dada tidak terlihat baik dimana pada bagian ujung sirip terlihat geripis.Sedangkan pada ikan perlakuan 0,130 $\mathrm{mg} / \mathrm{l}$ kondisi sirip dada terlihat tidak baik dimana terlihat sirip dada geripis, hal ini juga terjadi pada perlakuan $1,295 \mathrm{mg} / \mathrm{l}$ dimana sirip dada terlihat geripis yang menandakan tidak normalnya kondisi sirip dada pada setiap perlakuan yang dilakukan selama uji dilakukan.

\section{2) Sirip Perut}

Kondisi sirip perut pada ikan terkontrol dalam keadaan normal dan baik.Pada perlakuan $0,013 \mathrm{mg} / \mathrm{l}$ keadaan sirip perut baik dan normal, sedangkan pada perlakuan $0,130 \mathrm{mg} / \mathrm{l}$ kondisi sirip perut ikan terlihat tidak baik dimana terlihat rusak.Hal ini juga terjadi pada perlakuan 1,295 mg/l keadaan sirip perut yang dalam kondisi geripis dan rusak.

\section{3) Sirip Punggung}

Kondisi sirip punggung pada perlakuan terkontrol dalam keadaan normal dan baik, hal ini juga terjadi pada perlakuan 0,013 mg/l dimana kondisi sirip punggung ikan dalam keadaan normal dan baik.Kondisi ini tidak terjadi pada perlakuan $0,130 \mathrm{mg} / \mathrm{l}$ dan 1,295 $\mathrm{mg} / \mathrm{l}$ dimana kondisi sirip punggung dalam keadaan tidak baik dimana sirip punggung rusak.

\section{4) Sirip Anal}

Keadaan sirip anal pada perlakuan terkontrol terlihat normal. Pada perlakuan 0,013 $\mathrm{mg} / \mathrm{l}$ kondisi sirip anal terlihat geripis, hal serupa juga terjadi pada perlakuan $0,130 \mathrm{mg} / \mathrm{l}$. Sedangkan pada perlakuan 1,295 mg/l kondisi sirip anal terlihat puntung.

\section{5) Sirip Ekor}

Kondisi sirip ekor pada perlakuan terkontrol terlihat normal dan baik tidak ada geripis, rusak dan puntung, kondisi ini tidak berlaku pada perlakuan $0,013 \mathrm{mg} / 1,0,130 \mathrm{mg} / \mathrm{l}$ dan $1,295 \mathrm{mg} / \mathrm{l}$ dimana keadaan sirip anus 
terlihat geripis bahkan pada perlakuan 1,295 $\mathrm{mg} / \mathrm{l}$ sirip anus sampai putung.

c. Kulit

Kondisi kulit pada masing-masing perlakukan terlihat normal, tidak ada terlihat luka selama penelitian dilakukan pada biota uji.hal ini dapat dilihat pada Tabel 1 diatas, selama pengamtan dilakukan pada ikan yang sehat, agak sakit,dan mati kondisi kulit normal selama pengamatan secara fisual yang dilakukan.Tamba (2004) menyatakan bahwa pengaruh pergerakan ikan Clownfish (Amphiprion percula) yang di berikan perlakuan penambahan minyak mentah dengan konsetrasi berbeda yaitu: (1) ikan bergerak tidak menentu, (2) ikan bergerak vertikal untuk mengambil oksigen ke udara bebas tidak menentu, (3) ikan bergerak di dasar akuarium tanpa daya, (4) pergerakan ikan secara vertikal tidak menentu dan tampak tidak berdaya, (5) ikan bergerak dengan keadaan ekor diatas dan kepala dibawah dengan posisi miring, dan (6) ikan melompat kepermukaan dan berusaha menembus permukaan minyak.

Tabel 3. Kondisi Morfologi Ingsang Awal Perlakuan dan Akhir Perlakuan Penambahan Minyak Mentah Pada Ikan Clownfish (Amphiprion percula)

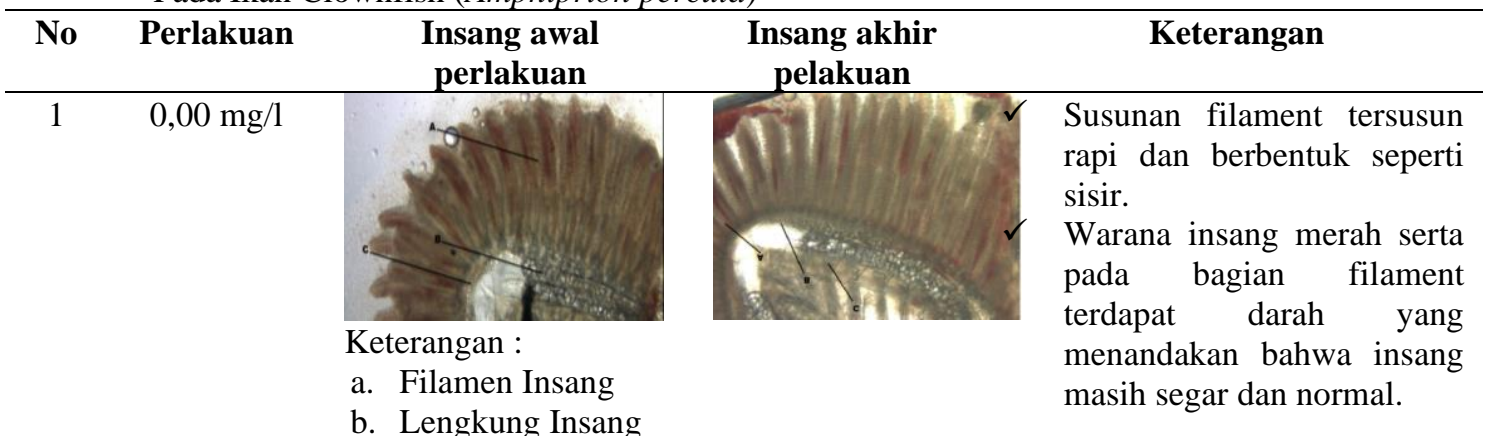

d. Insang

Hasil pengamatan insang ikan Clownfish (Amphiprion percula) pada perlakuan terkontrol terlihat normal. Hal ini ditandai dengan insang berwarna merah seperti sisir dan tidak terdapat tumpahan minyak mentah pada ingsang. Kondisi morfologi ikan Clownfish pada perlakuan terkontrol insang tersusun dengan rapi menyerupai sisir, bentuk filament yang rapat dan berwarna merah segar menandakan tidak adanya kontaminasi oleh minyak mentah.

Morfologi insang ikan Clownfish pada perlakuan 0,013 $\mathrm{mg} / \mathrm{l}$ mengalami kerusakan pada lembaran filament insanganya yang menjadi kurang rapat, serta insang terlihat tidak beraturan, warna insang yang tidak merah cerah melainkan berwarna merah pucat serta terdapat tumpukan minyak dibagian filament insang.Kerusakan morfologi insang ini disebabkan karena ingsang terkontaminasi oleh minyak mentah.Morfologi insang dapat dilihat pada Tabel 3 dibawah ini.

$2 \quad 0.013 \mathrm{mg} / \mathrm{l}$

\section{$0.013 \mathrm{mg} / 1$}

\section{c. Saringan Insang}

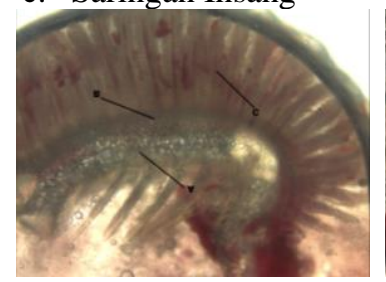

\section{Keterangan}
a. Saringan Insang
b. Lengkung Insang
c. Filament Insang

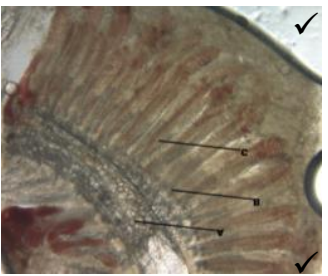

Filament insang terlihat sedikit ada celah, serta bagian antar filament terlihat ada minyak yang menempel pada permukaan filament.

Warna insang masih terlihat merah serta masih terdapat darah pada bagian filament yang menandakan insang masih dalam kondisi normal walaupun ada sedikt minyak pada bagian filament luar.

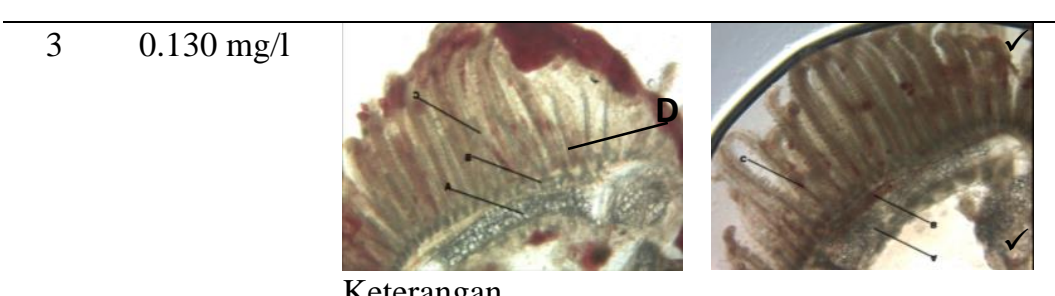

Keterangan
Kondisi insang tidak tersusun rapi seperti sisir, pada filament insang terlihat ada cairan berwarna kekuningan.

Warna insang terlihat merah pucat. 


\begin{tabular}{|c|c|c|c|c|}
\hline No & Perlakuan & $\begin{array}{c}\text { Insang awal } \\
\text { perlakuan }\end{array}$ & $\begin{array}{c}\text { Insang akhir } \\
\text { pelakuan }\end{array}$ & Keterangan \\
\hline 4 & $1.295 \mathrm{mg} / \mathrm{l}$ & $\begin{array}{l}\text { a. Saringan Insang } \\
\text { b. Lengkung Insang } \\
\text { c. Filament Insang } \\
\text { d. Minyak } \\
\text { Keterangan } \\
\text { a. Lengkung Insang } \\
\text { b. Filament Insang } \\
\text { c. Saringan Insang } \\
\text { d. Minyak }\end{array}$ & & $\begin{array}{l}\text { si insang tidak tersusun } \\
\text { i sisir, dimana terdapat } \\
\text { k pada bagian antar } \\
\text { nt, insang juga seperti } \\
\text { ong. } \\
\text { insang tidak berwarna } \\
\text { cerah melaikan } \\
\text { rna merah pucat. }\end{array}$ \\
\hline
\end{tabular}

(Sumber : Data Penelitian, 2018)

Kondisi morfologi insang ikan clownfish pada perlakuan $1,295 \mathrm{mg} / \mathrm{l}$ mengalami kerusakan pada bagian filament insang yang tidak lagi tersusun seperti sisir, serta banyak terdapat gumpalan minyak pada bagian filament insang yang mengakibatkan pertukaran darah dan air pada insang terhambat oleh gumpalan minyak mentah serta mengakibatkan pertukaran oksigen pada insang terhambat yang berakibat pada kamatian ikan Clownfish (Amphiprion percula). Warna insang pada perlakuan 1,295 mg/l berwarna merah keputihan bahkan menyerupai putih. Tingginya kerusakan struktur insang akan berpengaruh pada proses osmoregulasi. Menurut Fujaya, (2002) dalam Kusruni, (2007) menyatakan bahwa pada insang, terdapat sel-sel yang berperan dalam osmoregulasi adalah sel-sel choride yang terletak pada dasar lembaran-lembaran insang. Senyawa hidrokarbon yang terdapat pada minyak mentah dapat meningkatkan terbentuknya methemoglobin dalam darah sehingga menyebabkan transport oksigen menjadi terhambat dan darah kekurangan oksigen, selanjutnya pembuluh darah yang banyak terdapat pada filament brachial menjadi pecah sehingga daya serap oksigen berkurang.

Akibat kerja dari filament ini sebagai tempat pertukaran gas menjadi terganggu, dengan meningkatnya konsentrasi toksiskan yang diberikan pada unit percobaan jumlah karbon yang akan terpanjan pada insang akan Tabel 4.Pengamatan Kualitas Air selama Penelitian

\begin{tabular}{cccccccc}
\hline No & Perlakuan & Salinitas & Suhu ( $\left.{ }^{\mathbf{0}} \mathbf{C}\right)$ & DO (mg/l) & $\mathbf{p H}$ & Amoniak (mg/l) & Nitrit (mg/l) \\
1 & P0 & 33 & $26,4-26,7$ & $5,8-6,1$ & $7,89-7,94$ & $2,09-2,38$ & $0,74-0,74$ \\
2 & P1 & 33 & $26,4-26,5$ & $5,7-5,9$ & $7,94-7,96$ & $1,92-2,15$ & $0,68-0,72$ \\
3 & P2 & 33 & $27,1-27,4$ & $5,4-5,9$ & $7,79-7,89$ & $1,92-2,17$ & $0,62-0,74$ \\
4 & P3 & 33 & $26,8-27,1$ & $5,2-5,8$ & $7,83-7,92$ & $1,77-2,32$ & $0,57-0,75$ \\
\hline
\end{tabular}

membesar, sedangkan insang berfungsi sebagai alat pertukaran gas $\left(\mathrm{O}_{2}\right.$ dan $\left.\mathrm{CO}_{2}\right)$ (Nofyan dkk, 2011). Fakhrudin (2004) menjelaskan lapisan minyak juga akan menghalangi pertukaran gas dari atmosfer dan mengurangi kelarutan oksigen yang akhirnya sampai pada tingkat tidak cukup untuk mendukung bentuk kehidupan aerob. Hal ini mengakibatkan terganggunya proses pertukaran gas yang terjadi di dalam insang terhambat sehingga mempengaruhi proses respirasi yang terjadi pada insang, sehingga ikan menjadi kekurangna oksigen yang gunanya untuk mempertahankan kelangsungan hidup, apabila hal ini terus terjadi secara terus berlangsung berakibat pada kematian pada ikan. Proses kematian, emulsifikasi merupakan sumber kematian, terutama pada telur, larva, dan perkembangan embrio karena pada tahap ini sangat rentan pada lingkungan (Fakhrudin, 2004).

\section{Kualitas Air}

Salah satu faktor yang sangat menentukan dalam kehidupan ikan adalah kualitas air. Adapun paramenter kualitas air yang diukur dalam penelitian ini ialah suhu, salinitas, $\mathrm{pH}, \mathrm{DO}$, dan Amoniak $\left(\mathrm{NH}_{3}\right)$. Adapun hasil dari pengukuran kualitas air dalam penelitian penambahan minyak mentah dengan konsentrasi berbeda terhadap mortalitas ikan Clownfish (Amphiprion percula )di sajikan dalam bentuk Tabel 4 di bawah ini.

(Sumber : Data Penelitian, 2018) 


\section{a. Suhu}

Berdasarkan hasil pengamatan suhu sebelum dan sesudah penelitian yaitu kisaran $26,5-27,5^{\circ} \mathrm{C}$, kondisi suhu masih dalam batas optimal untuk kelangsungan hidup ikan Clownfish (Amphiprion percula). Suhu mempengaruhi aktivitas metabolisme organisme, secara umum laju pertumbuhan meningkat sejalan dengan kenaikan suhu, sehingga dapat menekan kehidupan biota bahkan dapat menyebabkan kematian bila peningkatan suhu sampai mencapai ekstrem (Kordi, 2009) dalam Utami (2013), yang menyatakan suhu perairan tropis berkisar anatara $25^{\circ} \mathrm{C}-32^{\circ} \mathrm{C}$ masih layak untuk kehidupan organisme di perairan. Perubahan suhu berpengaruh terhadap proses fisika, kimia, dan biologi badan air, peningkatan viskositas, reaksi kimia, evaporasi dan volatilasi. Peningkatan suhu juga menyebabkan penurunan kelarutan gas dalam air, misalnya gas $\mathrm{O}_{2}, \mathrm{CO}_{2}$, $\mathrm{N}_{2}, \mathrm{CH}_{4}$.

\section{b. Salinitas}

Berdasarkan hasil pengamatan salinitas sebelum dan sesudah penelitian yaitu 33, salinitas masih dalam batas optimum pada ikan Clownfish (Amphiprion percula). Salinitas air berpengaruh terhadap tekanan osmotik air, semakin tinggi salinitas, akan semakin besar pula tekanan osmotik. Biota yang hidup diair asin harus mampu menyesuaikan diri terhadap tekanan osmotik dari lingkungan (Kordi, 2007).

\section{c. Oksigen Terlarut (DO)}

Oksigen terlarut pada masing-masing perlakuan masih dalam batas optimum dan dapat ditolerir, hasil pengamatan DO menunjukan nilai awal $6,2 \mathrm{mg} / \mathrm{l}$ dan nilai akhir yaitu 5,2-6,1 mg/l. Konsentrasi oksigen terlarut yang rendah merupakan faktor yang lazim menyebabkan mortalitas pada ikan, kelarutan oksigen dalam air menurun kalau suhu dan kadar garam meningkat atau tekanan udara menurun (Effendie, 2000). Murdjani (2009), konsentrasi oksigen dalam air berpengaruh terhadap pertumbuhan dan konversi pakan, konsentrasi oksigen terlarut merupakan salah satu faktor yang membatasi bagi kehidupan ikan yang dibudidayakan

\section{d. $\mathbf{p H}$}

Hasil pengamatan $\mathrm{pH}$ sebelum perlakuan menunjukan nilai 7, 96 dan sesudah perlakuan diperoleh hasil pengamatan $\mathrm{pH}$ yaitu 8,3-7,96 konsentrasi $\mathrm{pH}$ air tersebut menunjukan bahwa kadar $\mathrm{pH}$ di air masih sesuai dengan batas untuk kelangsungan hidup ikan Clownfish (Amphiprion percula) angka konsentrasi $\mathrm{pH}$ dari hasil uji laboratorium sesuai dengan baku mutu dari air laut untuk biota laut sesuai dengan
Keputusan Menteri Lingkungan Hidup No. 51 Tahun 2004.

\section{e. Nitrit}

Nitrit merupakan bentuk peralihan antara amonia dan nitrat serta antara nitrat dan gas nitrogen yang biasa dikenal dengan proses nitrifikasi dan denitrifikasi (Effendi, 2000). Dalam penelitian ini lakukan uji nitrit pada selama penelitian, dimana hasil yang diperoleh pada awal penelitian sebesar $0,84 \mathrm{mg} / \mathrm{l}$ dan hasil uji pada akhir penelitian nilai kisaran sebesar $0,57-0,75 \mathrm{mg} / \mathrm{l}$.

\section{KESIMPULAN DAN SARAN}

\section{a. Kesimpulan}

Berdasarkan hasil penelitian yang dilakukan maka dapat disimpulkan sebagai berikut ini:

1. Dalam penelitian menunjukan bahwa ikan Clownfish masing-masing perlakuan mengalami stress karena adanya kandungan senyawa hidrokarbon mengakibatkan tingkah laku ikan tidak menentu. Selain itu hal ini juga berpengaruh pada senyawa kimia pada minyak mentah dapat merusak bentuk badan dan insang karena adanya tumpuk minyak mentah pada lampiran filament yang menghalangi proses respirasi, pada kulit dalam penelitian ini dalam kondisi normal tidak ada luka.

2. Dari uji laboratorium yang dilakukan pada kualitas air dimana penambahan minyak mentah berpengaruh pada perubahan kualitas air pada parameter amoniak dan nitrit yang memiliki hasil yang ditinggi dari baku mutu yang di keluarkan KepMen No 51 Tahun 2004. Hal ini menyebabkan terjadinya toksik pada ikan Clownfish (Amphiprion percula) yang menyebabkan kematian.

\section{b. Saran}

Saran yang dapat diberikan berdasarkan hasil penelitian yang dilakukan perlu adanya dilakukan uji terhadap kandungan minyak yang ada di dalam darah, lambung dan hati pada ikan clownfish (Amphiprion sp) untuk mengetahui lebih lanjut tingkat kerusakan organ selain dari ingsang bila dalam jangka panjang 


\section{DAFTAR PUSTAKA}

Effendie, H. 2000. Telaah Kualitas Air Bagi Pengelolahan Sumberdaya dan Lingkungan Perairan. Kanisius. Yogyakarta.

Fahrudin. 2004. Dampak Tumpahan Minyak Pada Biota Laut. Career Development Network, Jakarta: Faculty of Engineering University of Indonesia.

Kementrian Lingkungan Hidup No. 51 tahun 2004. Tentang Baku Mutu Air Laut

Kordi, M.G.H, Tanjung, A.B. 2007. Pengelolahan Kualitas Air. Rineka Cipta.

Kusnuri, E. Kharisma, N.H. Sucipto, A.Ahmad, M. 2007. Anatomi Organ Pencemaran Ikan. Program Studi Ilmu Perairan. Sekolah Pasca Sarjana. Institut Pertanian Bogor. $43 \mathrm{hlm}$.

Murdjani, M. 2009. Budidaya Clownfish (Amphiprion). Ditjen Perikanan Budidaya. Balai Besar Pengembangan Budidaya Laut Lampung.

Nofyan, Erwin, EP Sagala dan Vivit Suryani. 2011. Pengaruh Minyak Mentah Terhadap Mortalitas dan Morfologi Ingsang Ikan Bandeng (Chanos Chanos Forskäl). Maspari Jurnal. 02 : 19-25.

Nuryatini dan Edi Iswanto Wiloso, 2010. Uji Metode Analisis Minyak Terdispersi Dalam Air. Jurnal Teknologi Indonesia, No. 262/AU/P2MBI/05/2010.
Peraturan Pemerintah No. 24 Tahun 1991. Tentang Pengendalian Pencemaran Lingkungan Laut.

Syafriadiman, Eryan Huri, dan Sampe Harahap. 2009. Toksisitas Limbah Cair Minyak Bumi Terhadap Benih Ikan Kerapu Bebek (Cromileptis altivelis). Berkala Perikanan Terumbuk. 37(1)

Setiawan, T.E, Hearuddin, dan C., Ain. 2014. Efisiensi Penggunaan Oil Water Separator Pada Kapal Penangkap Ikan Untuk Pencegahan Pencemaran Minyak di Laut (Studi Kasus KM. Mantis) Di BBPPI Semarang. Diponogoro Jurnal Of Maquares. 3 (3) 112-120.

Tamba, A. 2001. Petologi Ikan Kerapu Bebek (Cromileptes altivelis Burchell). Akibat Kandungan Berbagai Konsentrasi Minyak Mentah (Crude oil). Skripsi. Fakultas Perikanan dan Kelautan. 86 hal 